\title{
PARTNERS OR COMBATANTS: A COMMENT ON THE AUSTRALIAN TAX OFFICE'S VIEW OF ITS RELATIONSHIP WITH THE TAX ADVISING PROFESSION
}

\author{
JUSTIN DABNER
}

The approach to administration of the Australian tax system has, over time, fluctuated between an adversarial and a co-operative approach. Currently, consistent with a move to a responsive regulatory strategy, the Australian Tax Office ("ATO") has expressed its desire for a co-operative partnership style relationship with the tax advising profession. The profession is seen, in its view, as a critical leverage point to promote voluntary compliance with the tax system by the bulk of taxpayers.

The advent of a partnership style relationship between the ATO and the tax profession raises many issues, primary of which is whether the desire to establish this relationship is mere rhetoric employed by both parties in the pursuit of their divergent interests. In fact, the very existence of these opposing interests raises the possibility of ethical conflicts that need to be carefully managed by both parties to the partnership.

The ATO is to be commended for the humane and practical way in which the evidence in this case shows its officers dealt with persons who are in difficulties. That attitude indeed probably produces more actual cash into the Treasury than any other approach. It will occur from time to time that some taxpayer will abuse that approach. It may also be that the laws ... nowadays operate unfairly against the ATO. I hope that neither of these last two points will operate to change the general attitude.

Justice Young in Dean-Willcocks v FCT (2004) NSWSC 1058 (10 November 2004) at para 88.

\section{INTRODUCTION}

The 20th century has been described as a "great century for tax collection". 1 As the economic rewards of increasingly sophisticated technological societies have expanded together with the development of a greater social conscience governments have increasingly turned towards taxation as a means to fund social programs and public goods. The design of tax systems themselves have often been employed as a means to deliver social equity through the medium of tax expenditure programs. Furthermore, the increasing sophistication of modern commerce has meant that these tax systems have had to be able to respond to many and varied scenarios and transactions.

The result of this confluence of factors is that tax systems have become incredibly complex. Furthermore, the increasing size of the tax impost has presented a significant incentive for taxpayers to avoid their obligations. Thus the role of the tax collection authority has become increasingly important and, indeed, difficult.

Tax authorities around the world have approached the administration of their tax systems from the perspective that voluntary compliance is the linchpin of the success of the system. However the complexity of these systems has rendered it almost impossible for the average taxpayer to identify their tax liability and obligations. This

\footnotetext{
${ }^{*}$ Dr Justin Dabner, School of Law, James Cook University, Cairns Campus

${ }^{1}$ Attributed to Professor Christopher Hood in John Braithwaite, Markets in Vice Markets in virtue, The Federation Press 2005 at 18 (“Braithwaite 2005”).
} 
has led to the development of a new breed of financial and business adviser known as the tax advising professional.

The scope of the tax advising profession extends from tax preparers or agents at one extreme, who assist simple taxpayers to prepare their tax returns, through to highly qualified accountants and lawyers who assist large multinational companies to minimize their tax liabilities and contest disputes with the tax authority.

Tax authorities recognize that courting this new tax advising industry is critical to achieving their tax compliance goals. Certainly the evidence in Australia is that the significance of the tax advising profession has increased markedly with the advent of the self assessment system and the profession is considered as a key compliance leverage point to influence taxpayer behaviour. ${ }^{2}$

The response of the Australian Taxation Office (“ATO”) has been to avow that its relationship with the profession is one of a partnership. This is consistent with modern regulatory trends. However it will be suggested in this paper that if this label is accurate it raises many issues that need to be resolved. In particular issues as to conflicts of interest, transparency and accountability and the application of the partnership model need to be addressed.

\section{REGULATORY THEORY AND TAX ADMINISTRATION}

The different approaches to tax administration borrow from general regulatory theory. Regulatory theory traditionally has distinguished between the compliance approach and the deterrence or sanctioning approach. ${ }^{3}$ The compliance approach describes a cooperative problem solving approach in an ongoing working relationship between the regulator and the regulatees. Conformity, or near conformity, with regulatory requirements is intended to be achieved with sanctions as a last resort.

The deterrence approach, on the other hand, describes a regulatory style in which the regulator demands that the regulatory requirements are met or sanctions will be imposed.

These two approaches are best viewed as extremes of a continuum and real-world regulation involves a mix of the two with any particular regulator fluctuating between the two ends of the continuum depending on the current mindset derived from the political and socio-economic conditions of the time. ${ }^{4}$

This mix can also be reflected in what is commonly described as "responsive regulation" whereby a regulator's response to a regulatee's most recent conduct will be determined by the characteristics of the regulatee. ${ }^{5}$ So co-operative regulatees are responded to co-operatively and recalcitrant ones in a punitive manner. Theory

\footnotetext{
2 Australian National Audit Office, The Auditor-General Audit Report No 19 2002-03 Performance Audit: The Australian Taxation Office's management of its relationship with tax practitioners at 38-39 and 40. The profession would appear to have the ability to exert either a positive or negative influence on tax compliance. Higher qualified professionals tend to have a more negative effect on taxpayer compliance than lower end advisers: Maryann Richardson and Adrian Sawyer, "A taxonomy of the tax compliance literature: further findings, problems and prospects” (2001) 16 Australian Tax Forum 137 at $208-212$.

${ }^{3}$ K Hawkins, Environment and enforcement: regulation and the social definition of pollution, Oxford University Press, Oxford 1984 and A Reiss Jr, "Selecting strategies of social control over organisational life” in K Hawkins et al, Enforcing regulation, Kluwer-Nijhoff publishing, The Hague, 1984.

${ }^{4}$ Ibid.

${ }^{5}$ John Braithwaite, Restorative justice and responsive regulation, especially chapter 2 "Responsive regulation” at 29 - 44, Oxford University Press, Oxford 2002.
} 
supporting responsive regulation points to an enforcement pyramid, that is escalating steps directed at establishing compliance where interaction between the regulator and most regulatees will occur at the base of the pyramid representing co-operative measures. Non-co-operative regulatees will be met with increasingly punitive measures as they move up the pyramid. ${ }^{6}$

Recent "smart regulation" theories recognize that a regulator and regulatees operate in an environment where there are other regulatory stakeholders. The regulator can leverage off these stakeholders to more effectively achieve its compliance goals. ${ }^{7}$ Thus, for example, a tax administrator, in the pursuit of mandating compliance with the tax laws, might leverage off the need for company directors to comply with their corporate law obligations to shareholders and the corporate law regulator.

In the context of tax administration the deterrence theory translates into an adversarial relationship between the administrator and taxpayers and their advisers akin to the relationship between opposing counsel in a common-law system. Under this model the tax authority would administer and apply the law with a view to maximizing government revenue and pursuing government policy whilst the profession would seek to minimize the tax liabilities of its clients by employing tax planning techniques and / or asserting pro-taxpayer interpretations of the tax law.

At the other extreme, the co-operative approach, the tax authority and the tax profession might form a partnership with a view to minimizing conflict and seeking to achieve negotiated positions. Such an approach might be justified by the tax authority on the basis of the administrative cost savings and efficiency notwithstanding a possible loss of some tax revenue. ${ }^{8}$ Similarly the profession might justify such an approach for their clients on the basis of a compromise between the costs of a possible dispute with the tax authority and the desire to minimize tax payable. Notably, there appears to be no research as to which approach returns the best tax compliance dividend.

This co-operative approach is premised on the tax authority engaging with the community and being responsive to its concerns whilst being wary not to simply appease special interest groups at the expense of system integrity. ${ }^{9}$ As is discussed below, this raises the twin issues of as to whom in the community the authority should listen and how is it to filter what is put to it to maintain system integrity. In the particular context of engaging with tax practitioners it will be suggested that the profession is eclectic in nature and it can be expected that some members are very adept at negotiating an agenda for specific interest groups in the guise of more innocent concerns.

The regulatory history of the ATO reflects the various regulatory theories with the organization having fluctuated between the two extremes of compliance and deterrence within a command and control framework of regulation. ${ }^{10}$ Its approach might now be

\footnotetext{
${ }^{6}$ Ibid.

${ }^{7}$ N Gunningham, P Grabosky and D Sinclair, Smart regulation: designing environmental policy, Oxford University Press, Oxford, 1998.

${ }^{8}$ However some would suggest that the more conciliatory approach adopted by the ATO in recent years has and will continue to lead to greater tax revenues: "Carmody's softly softly approach delivers windfall” Sydney Morning Herald (27 June 2006) 36.

${ }^{9}$ Valerie Braithwaite, "Chapter 13 - Tax system integrity and compliance: the democratic management of the tax system” in Taxing Democracy: Understanding tax avoidance and tax evasion, Ashgate, Aldershot, 2003 at 269.

${ }^{10}$ Cynthia Coleman and Margaret McKerchar, "The chicken or the egg?: A historical review of the influence of tax administration on the development of income tax law in Australia” in John Tiley (ed) Studies in the history of tax law, Hart Publishing 2004 at 285. The tax administration and tax professionals during the 1950s enjoyed a co-operative relationship. The ATO's recent approach would
} 
described as firmly embedded in responsive regulation with its compliance pyramid approach. The ATO's hierarchy, at least, see a co-operative approach to taxpayers as the dominant approach, ${ }^{11}$ consistent with what appears to be an international trend. ${ }^{12}$ This has been expressed by the ATO as a desire to more fully establish a partnership approach with the profession. ${ }^{13}$ This is indeed part of a larger tax compliance strategy that the ATO has embraced. This strategy seeks to found the collection of tax revenue in the principle of voluntary compliance whilst identifying risk areas where ATO enforcement resources can be more efficiently focused. The move to this strategy was necessary as the ATO's pursuit of efficiency in the face of an increasingly complex tax system required a change from a manual return processing approach to a risk assessment approach. ${ }^{14}$

The particular feature of this strategy relating to the profession is the recognition that the profession and the ATO are in a relationship of mutual dependence. If the relationship with the profession is properly nurtured the ATO believes that it has the capacity to significantly increase the efficiency of the administration of the tax system with attendant cost savings. Presumably this might be achieved at a number of levels. Firstly, the profession might take a less aggressive approach to advice resulting in greater tax revenues. Furthermore, certain functions traditionally exercised by the ATO might be effectively delegated or outsourced to the profession - certainly a feature of the self assessment system. From the government's perspective an added bonus of a non-adversarial relationship between the collecting authority and the profession is the

appear to be reminiscent of the approach it adopted back then: p 308. Slater suggests that a co-operative relationship remained up to the 1960s but was damaged by the Whitlam Government whose policies led to many regarding tax as optional resulting in suspicion and distrust on both sides: AH Slater, "Tax in Australian society: an 80 year perspective” (2007) 81 Australian Law Journal 681 at 689.

11 Initially trialed by the Cash Economy Taskforce established in 1996: see Michael D’Ascenzo, “Chapter 1 - Tax Administration into the 21 ${ }^{\text {st }}$ century” in Michael Walpole and Chris Evans (eds) Tax Administration into the $21^{\text {st }}$ century, A Prospect Intelligence Report 2001 at $1-9$. Also see Valerie Braithwaite and John Braithwaite, "Chapter 19 - Managing taxation compliance: the evolution of the Australian Taxation Office compliance model” at 215 - 224.

12 See, for example the report on the $35^{\text {th }}$ annual meeting of the Study Group Asian Taxation Administration and Research (“SGATAR”) held in Singapore in November 2005. This is a forum for revenue authorities in the region to discuss ways to improve the administration of revenue collection. It currently has 13 members. The forum identified tax professionals as key influencers of compliance behaviour and that there was a need to shift from the traditional view of antagonism to the tax administrator seeing itself in partnership with taxpayers and their advisers: Gil Levy, "The importance of the relationship between the tax collector and the tax agent” (2006) 40 Taxation in Australia 473. Also see the United Kingdom's “working together” program, discussed in Australian National Audit Office, The Auditor-General Audit Report No 19 2002-03 Performance Audit: The Australian Taxation Office's management of its relationship with tax practitioners at 55.

13 Recently reiterated by the Commissioner: Michael D'Ascenzo, "A new relationship with the tax profession”, Taxation Institute of Australia - 21 $1^{\text {st }}$ National Convention, 6 April 2006 and also see "Living our values" $7^{\text {th }}$ International Tax Administration Conference, Sydney, Australia, 20 April 2006. Also see "Relationships between tax administrators and tax agents / taxpayers", a presentation by Michael D'Ascenzo to the Asia-Oceania Consultants Association general meeting, Manilla 11 November 2005 and Michael Carmody, "Revitalising the tax administration system: The Australian experience" Tax Administration Advisory Board Meeting, Phoenix, Arizona, USA, 11 - 12 January 2005.

${ }^{14}$ See Braithwaite 2005, chapter 5. For a discussion of the pressures motivating the change see Jenny Job and David Honaker, "Chapter 6 - Short-term experience with responsive regulation in the Australian Taxation Office” in Valerie Braithwaite (ed) Taxing Democracy: Understanding tax avoidance and evasion, Ashgate 2003 at 111. 
favourable message that it sends to multinational companies and other potential foreign investors. $^{15}$

\section{THE PARTNERSHIP IN PRACTICE}

The relationship between the tax profession and the ATO had reached an all-time low by 2002. The profession had been under enormous stress following a considerable period of tax reform. It had taken the view that inadequate assistance had been provided during a period in which many extra obligations had been imposed on it and, in particular, there was inadequate recognition of the pressures on the profession in the ATO's approach to compliance deadlines and penalties. This had followed a period where the ATO had adopted an aggressive, albeit belated, approach to certain mass marketed tax schemes. There had been a common view that the ATO's failure to respond to these schemes earlier was a tacit approval of them with the result that the ATO's belated audit activity and imposition of tough penalties was unfair. However it took considerable political pressure on the ATO to retreat from its aggressive position. In this environment tensions between the ATO and the profession resulted in threats by the profession to strike. This had the effect of bringing the ATO to the table to negotiate a renewed relationship. ${ }^{16}$

From this low point the ATO has embarked on an enhanced strategy of the provision of assistance and engagement with the profession on matters of significance. ${ }^{17}$ In addition to various procedural changes and improved services and information dissemination at the operational level ${ }^{18}$ the ATO committed to an improved consultative platform including a specific ATO Tax Practitioner forum. So, for example, a campaign to review the use of service trusts by professionals has been the subject of negotiation resulting in the ATO compromising considerably on its initial position. ${ }^{19}$ The application of controversial legislation imposing penalties on promoters of tax schemes continues to be the subject of consultation with the profession. ${ }^{20}$ The introduction of a consolidations regime for corporate groups has also been the subject of considerable consultation resulting in benign positions being adopted by the ATO together with an educational and assistance program. ${ }^{21}$ A collaborative approach has

15 There is evidence that punitive tax enforcement may encourage multinationals to move offshore: Robert Lee, "Where tax rates fall, multinational follow" Tax-News.com, London (22 May 2006) (www.tax-news.com/asp/story/story_print.asp?storyname=23681) last viewed 1 June 2006.

16 Discussed in Australian National Audit Office, The Auditor-General Audit Report No 19 2002-03 Performance Audit: The Australian Taxation Office's management of its relationship with tax practitioners at $85-86$.

${ }^{17}$ Id, 19-20 and see the recommendations of the Auditor-General detailed at 30-33 all of which were endorsed by the ATO.

${ }^{18}$ Discussed in Greg Farr, "Benefits gained from listening and responding to tax agents" (2006) 40 Taxation in Australia 602. In particular, the establishment of the ATO relationship manager program would appear to have been particularly effective, at least according to the ATO.

${ }^{19}$ See the report by the Inspector General of Taxation, Review of the Tax Office's management of complex issues - case study on service entity arrangements, 24 April 2007 available at http://www.igt.gov.au/content/reports.asp?NavID=9. As to the ATO's initial position also see Fiona Buffini and Allesandra Fabro, "ATO widens net on use of service trusts" (18 May 2004) The Australian Financial Review at 3. For the ATO’s ultimate position see TR2006/2.

${ }^{20}$ Discussed in John de Wijn, "Promoter penalties - getting the balance right" (2006) 40 Taxation in Australia 395. Also a National Tax Liaison Group Promoter Penalty Co-design Sub-committee has been established by the ATO.

${ }^{21}$ See Neil Olesen, "Income tax consolidation - legislation now complete” (2003) 37 Taxation in Australia 462. 
been adopted in developing guidelines on large company audits. ${ }^{22}$ This would all appear to be coupled with a more conciliatory approach to taxpayers generally. ${ }^{23}$

More recently the ATO has included in its statement of its compliance program for 2006/07 a new section focusing entirely on how it sees its relationship with tax practitioners. Essentially the chapter is laden with commitments to continue to consult, co-design and co-operate in all dealings impacting on tax practitioners. ${ }^{24}$ It has indicated that recent surveys have suggested that these commitments are being honored and that both tax agents and taxpayers feel that they were being treated fairly and with trust and respect. ${ }^{25}$

A reciprocal approach by tax practitioners has been acknowledged by the President of the Tax Institute who commented in the Institute's journal of August 2006 that it was critical "to foster an open and mature relationship with all levels of the ATO to ensure the best possible outcomes from our consultations". At the same time, however, he warns that the Institute must be vigilant to guard against mere rhetoric from the ATO. ${ }^{26}$

\section{A PARTNERSHIP OF FOES: LIMITS OF THE PARTNERSHIP MODEL}

Notwithstanding these developments pointing towards an increasingly collaborative relationship between the profession and the ATO the partnership model is not without its limitations and concerns.

\section{A What common interest?}

The essence of a partnership is a fiduciary relationship between the partners under which they undertake to pursue a common interest. ${ }^{27}$ Whether it is correct to describe the relationship between the ATO and the profession as one in the pursuit of a common interest must be questioned. It could be suggested that, in fact, the two parties have quite opposing goals and interests. At the very general level the ATO is seeking to maximize government revenue whilst the profession is seeking to minimize it. To expect parties from such opposing perspectives to form a partnership is arguably naive. The only common interest they have is to achieve their individual (opposing) aims in the most expeditious manner.

In fact, elements within the ATO may indeed recognize this incongruence because, whilst the bulk of commentary on this topic issuing from the organization is couched in terms of forming community "partnerships", at least one publication retreats from the use of the partnership description to describing the relationship as one of mutual

\footnotetext{
${ }^{22}$ Large business and tax compliance, ATO August 2006 available at www.ato.gov.au/large/content.asp?doc=/content/77914.htm.

${ }^{23}$ See footnote 67 following for examples of other concessional positions taken by the ATO.

${ }^{24}$ ATO Compliance Program 2006/07, ATO August 2006 at $72-78$ available at http://www.ato.gov.au/taxprofessionals/content.asp?doc=/content/77362.htm.

${ }^{25}$ The Commissioner summarises the findings of these surveys at www.ato.gov.au/print.asp?doc=/content/77123.htm.

${ }^{26}$ Andrew Mills, “Tax transparency - consulting with the ATO” (2006) Taxation in Australia 65.

27 The various State Partnership Acts define a partnership as persons acting in common with a view to profit. Such an arrangement is traditionally distinguished from a joint venture where the parties work together to further their private interests. A joint venture typically imposes less in the way of fiduciary obligations on the parties. Maybe this would be a more apt descriptor of any relationship that might be achievable between the profession and the ATO.
} 
interdependence whereby an interest in the efficiency of tax administration is shared. ${ }^{28}$ More particularly this shared interest might be described as the desire to ensure that the "correct" amount of tax is paid. This would require the profession to bring to the ATO's attention what it considers to be overly aggressive tax planning. The current Commissioner of Taxation has, in fact, appealed to the profession to adopt this approach. ${ }^{29}$ However, it begs the question as to what is the "correct" amount of tax and what is overly aggressive tax planning. It could be expected that the ATO would take issue with any deviation from its view of the law whilst the profession may well take an alternative interpretation. How two parties could be viewed as having a shared interest in the application of the tax laws when they do not have a shared view as to what these laws are is problematic.

If it can be said that there is a shared interest then the corollary is that the ATO should identify to the profession tax planning opportunities where taxpayers can legitimately reduce their tax liability. Whilst it might be that some concessionary rulings, such as that dealing with salary sacrifice, ${ }^{30}$ actually reflect such an approach it could be suggested that the ATO should be going further and audit taxpayers not just from the perspective of identifying tax shortfalls but also from the perspective of identifying missed opportunities to reduce taxation. ${ }^{31}$

\section{B Problems raised by conflicting interests}

If it is accepted that there is some common or shared interest between the profession and the ATO then it could be anticipated that the pursuit of this common interest will create conflicts for both the profession and the ATO in relation to their private interests. Which interests should prevail where the profession identifies a planning opportunity for its clients from a clear drafting error which is inconsistent with the proper administration of the tax system? What if a member of the profession identifies an error by the ATO in its client's favour? Is the profession expected to swear allegiance to the administration of the tax system just as lawyers swear allegiance to the courts? ${ }^{32}$ Similarly is the ATO duty-bound under the partnership model to lobby Government in relation to problems of fairness and inequity that it has unearthed ${ }^{33}$ and even to advise

${ }^{28}$ ATO, Strategic framework for the Tax Office’s relationship with tax agents, March 2005 at 3 . Also see "Relationships between tax administrators and tax agents / taxpayers", a presentation by Michael D’Ascenzo to the Asia-Oceania Consultants Association general meeting, Manilla 11 November 2005.

${ }^{29}$ See “It is the community's tax system", address to the Australasian Tax Teachers' Association $18^{\text {th }}$ annual conference, Melbourne, Australia, 30 January 2006. Since this paper was given the ATO has proposed a dob-in line for tax agents: referred to in a speech by the Commissioner to the Taxpayers Australia and Superannuation Australia Annual Conference, Sydney, 10 November 2006. However this has met with resistance from the profession: Elizabeth Kazi, "Tax dob-in line on hold” (27 November 2006) Australian Financial Review 1.

${ }^{30}$ TR 2001/10.

${ }^{31}$ One area were the profession is concerned that clients are missing benefits that they would otherwise be eligible to receive because agents are overwhelmed by the complexity of the legislation is consolidations: see the ATO's consultative forum, Small to medium enterprises sub-committee minutes for 25 November 2005.

32 The basic rule in most countries is that the tax professional must act in complete independence from the tax administration: Victor Thuronyi, Tax law design and drafting, IMF 1998 at 140.

33 As some have suggested: Pauline Niemirowski, Steve Baldwin and Alex Wearing, "Chapter 18 Thirty years of tax compliance research: of what value is it to the ATO?” in Michael Walpole and Chris Evans (eds) Tax Administration into the 21 $1^{\text {st }}$ century, A Prospect Intelligence Report 2001 at 199 - 213. This obligation appears to be recognized by the current Commissioner who recently stated that not only should the ATO co-design with business sensible administrative approaches that facilitate practical 
practitioners of missed deductions or even planning opportunities or is it compelled to maximize tax revenue for the government? ${ }^{34}$ And if there is alleged to be a breach of duty by either partner is this actionable and, if so, in what venue and what sanctions might be appropriate?

The notion that tax professionals may owe a duty or obligation to the tax system is very controversial. ${ }^{35}$ Some commentators suggest that the practitioner's role as an enforcer reflects their duty to act in society's best interests ${ }^{36}$ or that in seeking to earn profits and minimize costs professionals must be held accountable to some level of collective well being ${ }^{37}$ or that the exercise of professional judgment requires that advice be couched in the context of justice and good faith and lawyers, at least, are responsible to the community ${ }^{38}$ and to achieving a just termination of disputes. ${ }^{39}$ How this is reconciled with their role as an exploiter has led others to suggest that they act as

compliance and reduce compliance costs but also it should bring to the attention of Government matters where the tax laws are not operating according to the policy intent or which produce unintended consequences or unexpected and significant compliance costs: Michael D'Ascenzo, Address to the PricewaterhouseCoopers Boardroom Dinner, Brisbane, 28 June 2006.

${ }^{34}$ The need for the ATO to balance divergent interests between itself and the profession was recognized in Australian National Audit Office, The Auditor-General Audit Report No 19 2002-03 Performance Audit: The Australian Taxation Office's management of its relationship with tax practitioners at 46.

${ }^{35}$ Whilst the accounting and legal profession are subject to professional standards these are typically open-ended and subject to interpretation in practice. For example, see paragraph 20 of the Statement of Taxation Standards (APS 6) issued by the Institute of Chartered Accountants of Australia requiring members who become aware of a client's non-disclosure to "carefully consider whether [they] should continue acting for that client," although note paragraphs 25 and 26 which specifically mandate that Institute members should not associate themselves with tax schemes. (APS 6 available at http://nxt.pearsoned.com.au/NXT/gateway.dll/?f=templates\&fn=default.htm\&vid=ICAA:MembersHan dbook.Guest.Enu\&NPAC_CREDENTIALSPRESENT=TRUE.) Note that effective from 1 July 2008 APS 6 is to be replaced by APES 220, paragraph 7.6 of which also mandates that a client's failure to disclose should cause the member to reconsider their engagement. Similarly paragraph 5.4 provides that members should not promote or encourage tax schemes. Potentially of significance is paragraph 3.2 that provides that members shall observe and comply with their public interest obligations when they provide taxation services: Accounting Professional and Ethical Standards Board Ltd, APES 220 Taxation Services, October 2007 available at http://www.apesb.org.au/.

${ }^{36}$ See Rebecca L Attwell and Adrian J Sawyer "The ethical attitudes of New Zealand tax practitioners still "barely passing"?" (2001) 7(2) New Zealand Journal of Taxation Law and Policy 111 at 113, also citing PMJ Reckers, DL Sanders and RW Wyndelts, “An empirical investigation of factors influencing tax practitioner compliance” (1991) 13 The Journal of the American Taxation Association 30 at 32. See also LS Shapiro, “Doing what is right” (1996) 41(12) National Public Accountant 7.

${ }^{37}$ Don R Hansen, Rick L Crosser and Doug Laufer, "Moral ethics v Tax ethics: the case of transfer pricing among multinational corporations” (1992) 11(9) Journal of Business Ethics 679, disagreeing with Urmson quoted as suggesting that the duty of the tax practitioner is to assist the client in complying with the law and going beyond this requirement should be left to saints: Urmson, "Saints and heros" in Meldon (ed), Essays in Moral Philosophy 1958. For another appeal to tax practitioners to demonstrate a concern for moral considerations beyond that required by law or economic efficiency see Alan Stainer, Lorice Stainer and Alexandra Segal, "The ethics of tax planning” (1997) 6 Business Ethics 213.

38 Tony Greenwood, "Ethics and avoidance advice", presentation to the Australian Institute of Directors seminar The New Corporate Morality, Melbourne, 21 March 1991.

${ }^{39}$ Alvin B Rubin, “A causerie on lawyers' ethics in negotiation” (1975) 35 LA Law Review 577. Thus it is argued that a lawyer should not accept a result that is unconscionably unfair to the other party because, perhaps, the other party had acted on mistaken facts. This duty to the profession and society must supersede any duty to the client. On this basis full disclosures should be made to the Tax Authority (even of material it may not have requested) and it should be advised of deficiencies in the taxpayer's case. 
exploiters where the tax laws are ambiguous and enforcers where the tax laws are clear and unequivocal. ${ }^{40}$

Others decry any duty to the system. The Taxation Institute of Australia's then President stated in 1994 that the sole responsibility of the tax professional is to their client and if anyone has a duty to the community in regard to tax it is the taxpayer. Any duty the professional has is performed by discharging their responsibilities to their clients. $^{41}$ Surveys of both New Zealand ${ }^{42}$ and Western Australian tax practitioners ${ }^{43}$ have confirmed that few acknowledge a duty to the taxing authority or, indeed, to act in the public interest.

If it is indeed the case that tax advisers have no obligation to the system then it does not bode well for partnership relations. It also raises doubts as to the motives of tax advisers who purport to embrace the partnership model. If they have no regard for the interests of the system they might just be employing a subterfuge to surreptitiously promote the interests of their clients?

But, of course, the absence of some acknowledged duty to the system does not prevent practitioners adopting an ethical attitude that sees them balance the interests of their clients and society. If, indeed, tax advisers do exhibit high tax ethics then this would encourage the view that they might embrace the partnership model in the appropriate spirit. Unfortunately surveys to date seeking to assess the ethical attitudes of tax advisers suggest that they are "barely passing" 44 and there is considerable diversity among Australian tax practitioners in the ethical stances they take. ${ }^{45}$

This debate as to tax adviser loyalties goes to the heart of what we see as the role of tax advisers. During the late 1980s this became a contentious issue in the United States with the publication of the results of an Internal Revenue Service ("IRS") sponsored survey of tax advisers from which a negative impression was drawn by the IRS as to their impact on tax compliance. In their review of this development Jackson and Milliron suggested that the practitioner's role lies somewhere along a spectrum with government agent at one end and taxpayer advocate at the other. However there was disagreement between the IRS and practitioners as to where on the spectrum their role should lie. Whilst the practitioners acknowledged that they had a dual responsibility to the system and to clients the later was their primary responsibility whereas the IRS was attempting to force practitioners towards the agent end of the spectrum. ${ }^{46}$ Jackson and

${ }^{40}$ Maryann Richardson and Adrian Sawyer, "A taxonomy of the tax compliance literature: further findings, problems and prospects" (2001) 16 Australian Tax Forum 137 at 208 - 212 referring to the work of S Klepper, M Mazur and D Nagin, "Expert intermediaries and legal compliance: the case of tax preparers” (1991) 34 Journal of Law and Economics 205.

${ }^{41}$ David Russell QC, “The client’s interests always take priority” (1994) 28(8) Taxation in Australia 431. Also see AJ Myers, “Tax advice: the lawyers ethical responsibility” (1990) 19 Australian Tax Review $80-87$.

${ }^{42}$ Attwell and Sawyer, at 128 - 129 reporting a similar finding to ST Tooley, "Tax practitioners: towards an understanding of ethical problems and attitudes in taxation”, Paper presented at the 1992 AAANZ Annual Conference, Palmeston North, New Zealand.

${ }^{43}$ RL Marshall, RW Armstrong and M Smith "The ethical environment of tax practitioners: Western Australian evidence" (1998) 17 Journal of Business Ethics 1265 at 1273.

${ }^{44}$ See Tooley, supra and Attwell and Sawyer, supra at footnote 28 citing Y Song and TE Yarborough, “Tax ethics and taxpayer attitudes: a survey” (1978) 38 Public Administration Review 442. Compare RL Marshall, RW Armstrong and M Smith "The ethical environment of tax practitioners: western Australian evidence" (1998) 17 Journal of Business Ethics 1265 - 1279.

${ }^{45}$ Yuka Sakurai and Valerie Braithwaite, "Taxpayers' perceptions of practitioners: Finding one who is effective and does the right thing?” (2003) 46 Journal of Business Ethics 375 - 387.

${ }^{46}$ The then Director of Practice at the IRS, Leslie S Shapiro, wrote of the practitioners' responsibility to the tax system being paramount. Practitioners were expected to be fair and honest in their dealings with 
Milliron suggested that there was a potential danger for the government's interests in this redefinition in the role of tax advisers to the extent that it drove taxpayers away from tax practitioners. The effectiveness of the subtle outsourcing to the profession of the IRS's compliance mandate would be jeopardized. ${ }^{47}$

As is discussed below, the issue of the duties that tax advisers' owe and their exact role may, in turn, depend on the type of adviser and their exact retainer. That is, it may not be possible to generalise across the spectrum of different types of advisers due to their eclectic nature.

If tax practitioners do owe some duty to the system or are properly to be seen as agents of the taxing authority then how is this to be reconciled with their legal obligations to their clients. Together with the more esoteric duty of loyalty an adviser owes their client a duty of confidentiality. ${ }^{48}$ Conceivably disclosure of a client's circumstances to the ATO without their permission might expose the adviser to either common law or contractual liability or breach of professional rules. It is unclear as to whether and, in what circumstances, the fact that the client was in breach of the taxation laws would be a defence to such a claim. ${ }^{49}$

Irrespective of whether an adviser has an obligation or discretion to disclose a breach of the law, an adviser must always be cautious of not exposing themselves to liability under the taxation or criminal laws from their client relationships. Whilst a legal obligation or entitlement to disclose a breach of the law might provide a defence to any action by the client it would appear that the scope of the aiding and abetting provisions would not seem to encompass a simple failure to disclose as the focus is on the "commission" of a positive act. ${ }^{50}$ However there has been debate in recent years as to the possible extension of the good Samaritan laws to require citizens to disclose the commission of offences of which they are aware. ${ }^{51}$

With the advent of the ATO's partnership model the nature of the tax adviser's role assumes particular significance. The Commissioner in a recent controversial presentation spoke of his vision which allowed high levels of professional standards to be blended with social and ethical responsibilities. He suggested that tax professionals should give something back to the country in terms of balanced and constructive input on the shape of the tax system, intelligence on how it was operating on the ground ${ }^{52}$ and feedback on the quality of tax administration. They should be open about defects in the tax laws whether they exposed loopholes that disadvantaged the revenue or unintended consequences that disadvantaged taxpayers. The Commissioner conceded that the changes in thinking within the ATO were difficult and would take time but also called

the IRS and foster confidence in their clients in the integrity of the tax system and in complying with it: "Professional responsibility in the eyes of the IRS" (March 1986) The Tax Adviser 136 at 139.

47 Betty R Jackson and Valerie C Milliron, "Tax preparers: government agents or client advocates?" (1989) 167(5) Journal of Accountancy 76 - 83.

48 See Gino E Dal Pont, Lawyers’ Professional Responsibility, Lawbook Co 2006 at 75 - 78 and chapter 10.

${ }^{49}$ Id, chapter 10, especially at 231 and 234. Whilst disclosure of confidential information might be compelled by statute this is less likely where the confidential information is also subject to legal professional privilege in the absence of express provision: at 232.

${ }^{50}$ Id, 425 - 427.

${ }^{51}$ Andrew Ashworth, “The scope of criminal liability for omissions” (1989) 105 LQR 424.

52 The ATO has recently proposed a tax practitioner integrity line to enable tax agents to raise issues of concern about what they are seen in the marketplace: see Michael D”Ascenzo's speech to the Taxpayers Australia and Superannuation Australia Annual Conference, Sydney, 10 November 2006. 
upon the profession to reconsider its role in the care and management of the tax system. ${ }^{53}$

\section{The eclectic nature of tax advisers}

As noted above this issue is compounded by the fact that the partnership model also fails to appreciate that the tax advising profession is an eclectic group ranging from tax agents and suburban accountants to international tax advisers and tax barristers. ${ }^{54}$ Both the role they play and the approach of these individuals in dealing with the ATO differ significantly across the spectrum. It is universally acknowledged that accountants in a tax planning role typically approach a client's tax obligations with the view to processing them through the system as painlessly as possible whilst legal advisers tend to be more aggressive in the approach they mandate to dealing with the tax authority. ${ }^{55}$ Furthermore, recent experiences in the United States and Australia with tax schemes would suggest that the schemes are supply driven, at least initially, reflecting that the there is a very aggressive cohort of advisers who could not be said to share any common interest with the tax authority. ${ }^{56}$

The United States manual on tax practice standards ${ }^{57}$ acknowledges the distinction between an advocate, whose paramount duty is to zealously represent the client, and an adviser, whose pursuit of their client's interests may be constrained by a duty to see that the tax system is not improperly used by the taxpayer. Whilst acknowledging that there is a view that a practitioner's loyalty is solely to their client, the authors suggest that the better view is that the practitioner owes a duty to the system to encourage compliance with the law. ${ }^{58}$ The key to the relative weightings of the dual responsibilities depends on the extent to which the practitioner is engaged in adversarial proceedings, although it is acknowledged that this is not always easy to delineate. ${ }^{59}$ In particular, in disputes or, possibly, on an audit there is no duty to disclose adverse precedent or reveal unfavourable facts to the taxing authority. ${ }^{60}$ On the other hand, a tax planner's duty to the system may override the duty to the client, especially when filing a rulings request. ${ }^{61}$ When acting as a negotiator, whilst the practitioner is probably acting as an advocate, the authors counsel against whether an adversarial strategy will necessarily

\footnotetext{
${ }^{53}$ Michael D’Ascenzo, “Cultural shifts in thinking - what if?” address to the Allens Arthur Robinson dinner, 7 September 2006. The editor of the Australian Financial Review probably summed up the response of many practitioners to this presentation by suggesting that the Commissioner was "having himself, and us on" as this would simply create a climate of distrust: ATO needs better laws, not informers”, (9 October 2006) Australian Financial Review at 70. Also see Elizabeth Kazi, “ATO seeks informants" (6 October 2006) Australian Financial Review at 13.

${ }^{54}$ See Australian National Audit Office, The Auditor-General Audit Report No 19 2002-03 Performance Audit: The Australian Taxation Office's management of its relationship with tax practitioners at 41-44.

${ }^{55}$ See Victor Thuronyi, Tax law design and drafting, IMF 1998 at 148 . Also see Roman Tomasic and Brendan Pentony, “Tax compliance and the rule of law: from legalism to administrative procedure?” (1991) 8 Australian Tax Forum 85.

${ }^{56}$ Braithwaite 2005. Also see Prem Sikka and Mark P Hampton, “The role of accountancy firms in tax avoidance: some evidence and issues” (2005) 29 Accounting Forum 325.

${ }^{57}$ Bernard Wolfman, James P Holder and Kenneth L Harris, Standards of Tax Practice, Tax Analysts, $5^{\text {th }}$ edition, 1999.

${ }^{58} \mathrm{Id}, 4$ and 52.

${ }^{59}$ Id, 49 - 52. The stance that the adviser should adopt may depend on the nature of the penalty at issue is it designed to discourage certain conduct or merely impose an economic cost?

${ }^{60} \mathrm{Id}, 361,364$ and 366. But it might be advisable from a reputational perspective to advise the IRS of conflicting precedent.

${ }^{61}$ Id, $374-375$ and 413.
} 
best serve a client's interests and rather suggest that a co-operative strategy may be preferable. Regardless of the strategy adopted it is suggested that the appropriate goal is to seek to achieve the optimal result for the client. Thus concealment, puffery and other persuasive techniques would appear acceptable provided truthfulness is maintained. ${ }^{62}$ In contrast the tax authority and its advisers may have greater constraints on their pursuit of the Government's interests on the basis that they have a greater obligation to achieve a just outcome, although the authors acknowledge that this is open to debate. ${ }^{63}$

The distinction between roles and their respective obligations has been justified by other commentators on the basis that a tax system based on self assessment is by its nature a co-operative effort between taxpayers and the government and the effectiveness of the system is threatened by advisers who treat the return preparation and examination process as adversarial. Rather there is a duty to society on both advisers and taxpayers at the preparation and examination stage that requires full disclosure, including of opposing arguments and material not requested by the Taxing Authority, so that a considered debate can occur. It is inappropriate for taxpayers to "win" by default as can occur under an adversarial system. Only once a taxpayer has satisfied the disclosure requirements should advisers be free to advocate on behalf of taxpayer positions. These commentators suggest that tax advisers must respect their dual responsibilities and be prepared to put the good of the system ahead of that of client loyalty when clients refuse to disclose. ${ }^{64}$

Notably these commentators accept that an adversarial approach may nevertheless be called for at the dispute resolution level as distinct from the return preparation and examination level. Could it be that the partnership model should be limited to prelitigation/dispute processes?

However there is an emerging field of law known as "collaborative practice" which suggests that a shared problem resolving approach can be an appropriate model to resolve disputes. This model had its genesis in the practice of family law in the early 1990s but is now presenting as an alternative dispute resolution mechanism in other areas of practice. It is premised on the parties entering into written commitments to deal with each other in a collaborative way, making full disclosure and then each party and their advocates attempting to understand and accommodate the goals and interests of the other. In a sense the clients and their advocates work together as members of a partnership rather than against each other as opposing parties. This is a particularly useful model to sustain a positive relationship in cases where a continuing relationship between the parties is either designed or necessary. ${ }^{65}$ Its potential relevance to tax litigation is accordingly apparent although yet to be embraced. If the partnership model is to be properly viewed as applicable to the resolution of tax disputes as well as tax return preparation and administration generally then the collaborative practice procedure would appear to supply the appropriate methodology. However this would require commitment from both parties and a significant cultural shift.

\footnotetext{
${ }^{62}$ Id, 415 - 418. Contrast Alvin B Rubin, “A causerie on lawyers’ ethics in negotiation” (1975) 35 LA Law Review 577.

${ }^{63}$ Id, 497 - 498.

${ }^{64}$ Loren D Prescott Jr, "Challenging the adversarial approach to taxpayer representation” (1997) 30 Loyola of Los Angeles Law Review 693. Also see Alvin B Rubin, “A causerie on lawyers’ ethics in negotiation” (1975) 35 LA Law Review 577.

${ }^{65}$ Discussed in Karen J Levitt, "The emerging field of collaborative practice” (2006) 4 Collaborative Law Journal 14 and see the International Academy of collaborative professionals at www.collaborativepractice.com.
} 
The eclectic nature of the profession also makes it difficult for that ATO to identify professional associations that are truly representative of the profession with whom it can consult and engage. For example, the interests of suburban accountants and tax agents may not always be best represented by the Tax Institute and the Institute of Chartered Accountants as these bodies tend to be heavily influenced by individuals advising the big end of town. Furthermore, there is never a guarantee that these bodies are fully across the issues at the coalface of tax practice and may themselves be in some form of denial of the difficulties faced by practitioners as the existence of these problems may be perceived as an indictment of their own performance and relevance.

\section{$D$ The absence of transparency, the question of legitimacy and the loss of independence for the ATO}

Notwithstanding the rhetoric from the ATO hierarchy endorsing the partnership approach, the evidence is that the ATO has demonstrated inconsistency in its approach to the partnership model. It seems that sometimes it embraces a consultative and conciliatory approach whilst on other occasions it adopts an aggressive adversarial approach. Whilst this contrast in approaches may to some extent be reflective of its perception of the attitude of the relevant taxpayers towards compliance and, hence, reflect the enforcement pyramid at work this would not seem to justify all examples of inconsistency. ${ }^{66}$ As a result some taxpayers harbour a perception that the big end of town and high net worth individuals with their high level connections may be able to achieve more favourable outcomes from their "partnership" with the ATO than other taxpayers, such as employees and small businesses. ${ }^{67}$

${ }^{66}$ For example, the ATO's test case program was recently the subject of criticism by the Inspector General of Taxation for inappropriately being dominated by compliance objectives, lacking integrity and not respecting court decisions: see Elizabeth Kazi, “ATO forced to overhaul court tactics” The Australian Financial Review (8 August 2006) 1 and 6. Also the ATO's position on the exercise of its information gathering powers has been attacked as coercive irrespective of the co-operation showed by the taxpayer and therefore hardly consistent with mutual trust and co-operation: Fleur Anderson, “ATO retains right to raid” The Australian Financial Review (1 September 2006) 8. For further evidence of non-partnership like conduct see the references at footnote 82 following.

${ }^{67}$ Elizabeth Colman, “Tax office accused of granting favours to the big end of town” The Australian (3 March 2006) 21. This perception may be ill founded as recent concessionary positions taken by the ATO do not appear to be restricted to large business issues. For example, see the outstanding debts concession for small businesses instigated in June 2004 (discussed in Michael D'Ascenzo, presentation to the Council of Small Business Organisations of Australia, Melbourne, 27 June 2006), PS LA 2006/2 (statute barred private company loans made prior to the enactment of Div 7A of the Income Tax Assessment Act 1936 ("ITAA36”) are not deemed dividends), PS LA 2006/1 (the cost base for capital gains tax is not required to be reduced where Div 43 of the Income Tax Assessment Act 1997 ("ITAA97") deductions are not taken because the information to determine construction costs are not available), PS LA 2005/24 (Part IVA of the ITAA36 not to apply to typical husband and wife partnerships) (referred to in Fleur Anderson, “ATO gives ground on tax schemes” (14 December 2005) The Australian Financial Review 1), ATO media release Nat 2004,58, 4 August 2004 (superannuation recontribution strategies are not caught by Part IVA), ATO case analysis on Toyama Pty Ltd v Landmark Building Developments Pty Ltd at

http://www.ato.gov.au/taxprofessionals/content.asp?doc=/content/77529.htm (the decision, holding that whether the sale of real property was of input taxed residential premises depended on the subjective intention of the purchaser, is not to be followed due to the difficulties it generates for vendors) and TR 2006/2 (accepting the deductibility of services fees paid to services trusts). Whilst the later ruling is primarily relevant to the big end of town (or at least to their advisers) it presents an interesting example as the concessions contained therein have been the subject of criticism by some sectors of the media 
Whether this perception is correct or not it illustrates the transparency issues that arise from the partnership model. Whenever the ATO compromises or settles a tax dispute the issue arises as to why the ATO may have adopted a particular conciliatory approach on this particular issue whilst maybe adopting a more aggressive approach on another. Such conduct often creates a perception of bias for those taxpayers who have not been the beneficiary of the concession. Given that perceptions of fairness have been found to be significant in ensuring taxpayer compliant behaviour ${ }^{68}$ it is incumbent on the ATO to clearly enunciate the basis for any concessions it bestows. Whilst this issue is not peculiar to the partnership model it is much more likely to arise and presents a significant potential flaw in the model. ${ }^{69}$

In addition to the implications of decisions that prefer one taxpayer over another, the granting of administrative concessions also raises the issue of the powers of a tax authority to negotiate away tax revenue. ${ }^{70}$ In Ireland, for example, the co-operative compliance approach, as it might be described there, has been attacked by the profession on the basis that the Internal Revenue Service ("IRS") should apply the rule of law and has only limited discretion. Purported exercises of discretion are not only potentially ultra vires but can lead to bias, a perception of unfairness and discriminate against the compliant. Businesses that are not aggressive might thereby lose market share. Irish practitioners would seem to prefer their tax authority to be universally aggressive in its approach to applying the law. ${ }^{71}$ Otherwise the proposed bargain seems like "a bargain where one side is promising nothing and the other side is promising what they cannot deliver". ${ }^{72}$ All these comments are equally applicable to the ATO. The organization needs to be conscious of the limits of its authority in making decisions that have a tax policy element, particularly where the decision discriminates in favour of or against sections of the community.

To the extent that a collaborative approach by the ATO is, arguably, more likely to lead to tax amnesties and similar concessions the ATO needs to be cognizant of the literature on the implementation of tax amnesties that suggests that such amnesties tend to have negative revenue effects because of the negative signaling effect or due to the reduced fear of the consequences of further evasion / avoidance. ${ }^{73}$ Whilst there is some evidence that amnesties and concessions can be effectively instituted ${ }^{74}$ this literature

whereas the professional organizations continue to complain that the concessions achieved still do not go far enough and the ruling is harsh.

${ }^{68}$ For example, see Grant Richardson, “A preliminary study of the impact of tax fairness perception dimensions on tax compliance behaviour in Australia” (2005) 20 Australian Tax Forum 407.

${ }^{69}$ On October 12, 2007 the Inspector General of Taxation announced a review into the ATO's settlement activities in particular focusing on the effectiveness of governance processes and assurance measures in engendering confidence in ATO settlements, the alignment of these settlements with the compliance model and the effectiveness that transparency measures in relation to settlements have in addressing perceptions of potential favouritism: see further at www.igt.gov.au.

${ }^{70}$ As to the limits of the Commissioner's powers to negotiate and compromise see Ray Conwell, "The Commissioner's Discretion's and Indiscretions - Changing attitudes to the use of the Commissioner's Powers", Taxation Institute of Australia 9th National Convention, Adelaide 1990.

${ }^{71}$ PJ Henehan and Aidan Walsh, "Beware of tax officials bearing gifts in large cases” (2004) 17(2) Irish Tax Review 133 ("Henehan and Walsh"). Some Australian advisers would also seem to prefer a more robust approach: Braithwaite 2005 at 64.

${ }^{72}$ Henehan and Walsh, 140. It should be added, however, that the Irish model is solely focused on the relationship between the IRS and taxpayers and seeks to sideline the tax profession.

${ }^{73}$ Adrian Sawyer, "Targeting amnesties at ingrained evasion - a New Zealand initiative warranting wider consideration?” Australasian Tax Teachers Conference, Wellington, New Zealand, January 2005.

${ }^{74}$ Id, 3 - 15. Also see DJ Hasseldine, “Tax amnesties: an international review” (1998) 52 (7) Bulletin for international Fiscal Documentation 303. 
illustrates that the partnership model may need to be adopted by the ATO with caution or even selectively if a compliance dividend is to be achieved.

Associated with the transparency issue is the risk to the ATO of exploitation of the model by the profession and / or interference in its implementation by the Government at the behest of lobby groups. The ATO needs to establish very clear parameters on which it is prepared to negotiate and compromise. Given that tax issues typically have a very public face the profession can be expected to use all means at its disposal to influence the outcome, means unavailable to the ATO. This may include publicity supporting its position as well as lobbying politicians and other functionaries, for example the Tax Ombudsman and Inspector-General, with the aim of putting pressure on the ATO. ${ }^{75}$ Further there is also no guarantee that the profession will see a negotiated position as an end but rather maybe as a beginning. That is, poorly qualified concessions by the ATO might be adopted by the profession as the basis for further tax minimization opportunities. Also they might be used as precedents in further negotiations. ${ }^{76}$

Certainly there are dangers from the model for the independence of the tax authority. ${ }^{77}$ The potential for conflicts of interest is not restricted to the profession. Grbich argues that the conflicts of interest for the ATO are such that it can be readily manipulated into pandering to the concerns of big business and its advisers. The risk is that it adopts a too compliant attitude to the views of taxpayers, its so-called "clients", ${ }^{78}$ and puts too little emphasis on protecting the revenue base. Ultimately institutionalized tax avoidance might be sanctioned ${ }^{79}$ and the "regulatory capture" is exploited by business advisers fully aware of the tactical advantage that the collaborative approach hands them. The partnership model, in Grbich's words, can have the result that:

The raping, plundering barbarians, the very taxpayers who competed so hard for the Olympic gold as Australia's most recalcitrant tax compliers, have been given the combination to the lock of the royal harem and Crown jewel house. ${ }^{80}$

\footnotetext{
${ }^{75}$ For example, see the complaints raised with the Inspector-General by corporations as publicized in Allesandra Fabro, “ATO hard line faces scrutiny” The Australian Financial Review (14 August 2005) 3. Either the ATO seems to have a patchy co-operative culture or the profession is using all the resources at its disposal to achieve the best results for its clients.

${ }^{76}$ As an example of intervention by the Inspector-General and pressure placed on the ATO to extend settlement concessions to a wider group of taxpayers see Katharine Murphy and Elizabeth Colman, “Taxman told to offer better deal in dispute” The Australian (1 March 2006) 31.

${ }^{77}$ Yuri Grbich, “After Bellinz and Ralph: a new focus for decision-making in the Australian tax system” in Michael Walpole and Chris Evans (eds), Tax administration into the $21^{\text {st }}$ century, Prospect Media 2001 at 11.

${ }^{78}$ In New Zealand the terminology that has been adopted is "customers”. Prebble would apparently share Grbich's concerns as he attacks the change in terminology and the use of "fairness" mottoes by the Internal Revenue Department as creating unreal expectations and internal uncertainty as to the role of the taxing authority. Such language smacks of a too greater desire to be flexible in applying the law in an attempt to appease taxpayers: John Prebble, "Chapter 7 - Customers, branding, mottoes and the New Zealand Inland Revenue Department” in Michael Walpole and Chris Evans (eds) Tax Administration into the $21^{\text {st }}$ century, A Prospect Intelligence Report 2001 at $83-88$.

${ }^{79}$ Mark Burton, "Taxation of intergenerational wealth transfer - the next tax compliance runaway train?, Unpublished Manuscript, University of Canberra 2004.

${ }^{80}$ Yuri Grbich, “After Bellinz and Ralph: a new focus for decision-making in the Australian tax system” in Michael Walpole and Chris Evans (eds), Tax administration into the $21^{\text {st }}$ century, Prospect Media 2001 at 11.
} 


\section{A PARTNERSHIP IN NAME BUT WHO IS KIDDING WHO: MUTUAL INTEREST OR SELF INTEREST?}

Professor Parsons once said in relation to the application of the general anti-avoidance rule that tax avoidance is a game in which you can win as long as it does not appear that you are trying to win. ${ }^{81}$ In a similar vein, the limitations of the partnership model raise a suspicion that the so called partners are not sincere in their apparent attempts to forge a partnership. That is, they do not trust each other, nor maybe should they. Could it be that both the ATO and the profession see the rhetoric of partnership as a tactic to be employed in the adversarial combat in which they are engaged?

There is ample evidence that either the ATO is, at worst, not sincere or, at best, the cooperative model is failing to filter down from senior management to the auditors. For example, in 2005 the ATO and the Corporate Tax Association commissioned a report in response to concerns that large corporations remained dissatisfied with their relationship with the ATO notwithstanding the ATO's supposed adoption of the cooperative approach. Senior executives of fifteen of some of the largest companies were interviewed by a non-partisan investigator. His findings were that the companies were of the view that frequently the co-operative approach was not reciprocated by ATO staff. It was thought that some in the ATO saw co-operation as a one-way street which may well have been beneficial to the ATO but that companies were receiving little in the way to assist them with their problems in return. In turn this perceived lack of reciprocity was unlikely to encourage the level of co-operation sought by the ATO. ${ }^{82}$

Of course the companies in their responses to this enquiry may also have been engaged in a game of brinkmanship attempting to exhort an even more conciliatory approach by the ATO. Nevertheless, and rather surprisingly, the ATO has even admitted that it sees the co-operative approach as a means to gather intelligence. ${ }^{83}$ Whilst this may seem a reasonable strategy and the Commissioner is to be applauded for his honesty its acknowledgement is hardly likely to assist in gaining the trust of the profession.

The criticisms of the ATO in the Inspector-General of Taxation's 2005-06 report might also suggest that the ATO is either not sincere or has a long way to go. This report suggested that the ATO culture needed to change from a defensive posture to one that accepted and acknowledged errors. Furthermore, it was failing to deliver on its commitment to not prejudging taxpayers and being flexible and transparent in its approach to settlements. Most telling the report suggested that the ATO had even failed

\footnotetext{
${ }^{81}$ Ross Parsons, “Income Taxation - An Institution In Decay” 3 (1986) Australian Tax Forum 233 at 259.

${ }^{82}$ Kevin Burges, Report on the concerns of a number of the largest companies in the large business segment, with ATO audit, investigation, and advice procedures, 30 April 2005 especially at $26-28$. The ATO has indicated that it is responding to these findings; "The way forward for the Tax Office", speech by Michael D'Ascenzo to the Pricewaterhouse Coopers CFO quarterly dialogue breakfast, Sydney, 10 May 2006. Also see Cynthia Coleman and Margaret McKerchar, "The chicken or the egg?: A historical review of the influence of tax administration on the development of income tax law in Australia” in John Tiley (ed) Studies in the history of tax law, Hart Publishing 2004, 285 at 308 - 309 where it is suggested that whilst the ATO denies that the current tax climate is adversarial this view is not shared by tax professionals. Furthermore, practitioners who attend the consultative meetings claim that they are frustrating and rarely lead to achievable outcomes.

${ }^{83}$ See Braithwaite 2005, chapter 13 and also comments by the Commissioner Michael D'Ascenzo in "It is the community's tax system”, address to the Australasian Tax Teachers' Association $18^{\text {th }}$ annual conference, Melbourne, Australia, 30 January 2006.
} 
to deliver in its professed partnership with the Inspector-General himself by employing delaying tactics and otherwise hindering the Inspector-General's reviews. ${ }^{84}$

The sincerity of practitioners towards the partnership model is also questionable. There is some evidence that they simply pay lip service to it as a strategy to further the interests of their clients. This is implicit in the apparent reluctance to acknowledge any duty to the system and the primacy given to clients' interests in surveys of the profession. $^{85}$ It is also implied from the findings of Tomasic and Pentony who conducted 141 interviews with tax practitioners and ATO employees during 1989 1990 primarily focused on perceptions of the rulings systems. ${ }^{86}$ Interestingly they found that an informal and co-operative approach existed between the ATO and the profession at the time with aggressive tax schemes a rarity. Apparently a change in style of practice had occurred away from the adversarial approach of the 1970s due to increases in perceived risk levels, namely the less legalistic approach of the judiciary, greater powers of the ATO (especially the availability of the general anti-avoidance provisions of Part IVA) and the increased costs of litigation. It would appear that something shortly happened to change the mindset of practitioners given the prevalence of schemes that sprang to life during the 1990s. Possibly one factor was the ATO's initial hesitance in applying Part IVA. Maybe, as Braithwaite suggests, this is just a cyclical pattern a generation behind the United States. ${ }^{87}$ In any event, as at 1990 Tomasic and Pentony found that practitioners tended to rely on a "smell test", not as to whether an arrangement was in accordance with the law but rather whether it was likely that the ATO would contest it. Thus practitioners were not so much focused on the "spirit of the law" but rather the "spirit of the times". This raises another possible driver of the tax schemes of the 1990s, the very conciliatory and co-operative approach that the ATO was demonstrating at the start of the decade. Maybe practitioners see the increasingly co-operative nature of the ATO as a weakness to be exploited which, in turn, will generate or contribute to a bust and boom cycle. ${ }^{88}$

\footnotetext{
${ }^{84}$ Inspector-General of Taxation Annual Report 2005-06, Commonwealth of Australia, October 2006 (http://www.igt.gov.au/content/reports/2005_06_annual_report/html/contents.asp) reported in Elizabeth Kazi, “ATO lashed over unfair tactics” (24 October 2006) Australian Financial Review 1 and 6 and also see Elizabeth Kazi, “Tax Inspector to watch his words” (3 November 2006) Australian Financial Review 3. Also see the Inspector-General's announcement of a review of GST audits. This review follows concerns that the ATO is pursuing matters that result in no net return for the revenue and are trivial, is over-penalising taxpayers, fails to understand industry practice and is employing unfair tactics and taking too long: Inspector General of taxation web site at

www.igt.gov.au/content/work_program/20061030.asp. If these concerns are validated this adds credence to the view that a partnership relationship is not materialising in practice. The Inspector General's Review into the ATO's management of tax litigation was also highly critical of the ATO's lack of objectivity and fairness and failure to seek to resolve matters at an early stage: http://www.igt.gov.au/content/reports/Litigation_report/default.asp

${ }^{85}$ See the references at footnotes $41-43$ below.

${ }^{86}$ Roman Tomasic and Brendan Pentony, "Tax compliance and the rule of law: from legalism to administrative procedure?” (1991) 8 Australian Tax Forum 85. Again a distinction was apparent between the views of accountants and solicitors. Accountants place more importance on a good nonadversarial relationship with the ATO than solicitors appear to.

${ }^{87}$ Braithwaite 2005 at 17 . Also see pages 37 - 42 for a brief history of aggressive tax planning in Australia.

${ }^{88}$ Cf Braithwaite 2005 at 177 - 178. He argues that regulatory agencies must not enter into a see-saw between a persuasive approach and a heavy handed approach. Rather a persuasive approach should be coupled with an escalation process to punish the recalcitrant. This is his thesis of "responsive regulation”.
} 


\section{CAN THE PARTNERSHIP MODEL WORK?}

If we assume that responsive regulatory theory is correct and a partnership style relationship between the ATO and the profession will return the greatest compliance dividend and if, irrespective of the doubts raised above, we assume that the parties are sincere in their efforts to implement the partnership model then how can the limitations of the model be best resolved and what features might enhance its chances of success?

The analysis here would suggest that a change in mindset of both practitioners generally and at all levels of the ATO is necessary. Express acknowledgement of conflicting duties and interests together with agreement on expectations is necessary. This applies equally to the ATO as well as to the profession. The establishment of parameters by which to delineate the appropriate response by the ATO and consistency of treatment are critical. If, as the ATO's compliance model would suggest, a more aggressive and adversarial approach is sometimes warranted the circumstances in which this approach will be employed must be clearly articulated and the decisions made transparent. The adversarial approach needs to be quarantined to those identified circumstances if the trust of the profession is to be garnered.

Indeed, the partnership model must be viewed against the background of the principles of good tax administration. Whilst tax administration must be both effective (capable of achieving a high level of compliance) and efficient (capable of minimizing administrative costs per unit of tax revenue) it must also satisfy the criteria of fairness, transparency and accountability. ${ }^{89}$ Unless the partnership model is carefully handled by the ATO there is a risk that effectiveness and efficiency considerations can dominate at the expense of the other criteria.

The partnership model should not be viewed in isolation from other endeavours to improve the administration of the tax system and reduce avoidance. The lowering of tax rates, the broadening the tax base and the removal of anomalies all serve to limit the avoidance opportunities and incentive. Furthermore, if a cultural shift can be managed to change the attitudes of taxpayers and advisers towards a more compliant mentality then in this environment the partnership model is more likely to flourish.

\section{CONCLUSION}

The hierarchy of the ATO has set Australian tax administration on a new course. A partnership or collaborative relationship with the profession is to replace the traditional adversarial approach. The ATO hopes that, together with responsive regulation and its enforcement pyramid, the partnership with the profession will encourage voluntary compliance and return a compliance dividend for the Government.

The partnership model has been embraced by the ATO hierarchy with zealous enthusiasm. However its successful implementation is not assured. This paper has sought to identify that many issues need to be explored and resolved. Further research on advisers' perceptions of their role and relationship with the ATO would inform the question as to whether the partnership model is, indeed, realistic and what more needs to be done to implement it at the "coalface". In addition, research on strategies that

\footnotetext{
89 Anuphan Kitnitchiva, "Accountability and fairness in tax administrations - a case study of the Thailand revenue department” (March/April 2006) Asia-Pacific Tax Bulletin 76.
} 
have been employed in other countries would also be valuable. ${ }^{90}$ The model is very much a work in progress.

${ }^{90}$ In particular the United Kingdom “working together” program (refer to footnote 12) and the approach adopted in New Zealand should be explored. Notably the United States does not appear to have had a positive experience from its attempts at adopting a more co-operative approach: see Braithwaite 2005 at 133 and 177. Also see HJ Aaron and J Slemrod, The crisis in tax administration, Washington: Brookings Institution Press, 2004. 